\title{
The Black Notebooks: implications for an assessment of Heidegger's philosophical development
}

The recent publication of Heidegger's so-called Black Notebooks, and the reflections it contains from the period of the Second World War, ${ }^{1}$ has revived an old controversy. Heidegger's endorsement of National-socialism is nothing new and, with few exceptions (Faye 2005) ${ }^{2}$ it did not produce any radical revision of his theoretical contribution to philosophy. Even if Heidegger's political choices have been widely perceived as disturbing, it has been usually possible to keep apart his 'human mistakes' from his intellectual endeavors. This is far from an unusual attitude: after all, the fact that Konrad Lorenz compromised himself heavily with the Nazi regime and its eugenic program was not a decisive hindrance to his being awarded the Nobel Prize in 1973. As for Heidegger's antisemitism, at first glance, it could be interpreted as a personal inflection of the cultural antisemitism that was widespread in Europe in the period between the two World Wars (and, actually, well before them). Thus, it was possible to argue that Heidegger's antisemitism was neither personal nor vulgarly biological, as Hans Jonas $(2005)^{3}$ concedes and as can be deduced from Heidegger's personal relations with Hannah Arendt, Karl Löwith, Elisabeth Blochmann, etc. Indeed, the list of prominent figures of European culture who expressed instances of cultural antisemitism is vast, including not only German authors like Carl Schmitt and Ernst Jünger, but also intellectuals like L.-F.Céline, D.H. Lawrence, T.S. Eliot, Ezra Pound, etc. We may deplore this cultural distortion, but this has rarely been a decisive ingredient in discussions of the content of the relevant works and appraisals of its value.

Why should it be any different in Heidegger's case? Is there anything new and specific that a careful reading of the $B N$ could provide with regard to an evaluation of Heidegger's thought? In fact, we believe there is something new, substantial and pertinent to a re-interpretation of Heidegger's thought, and we are going to devote the following pages to a concise attempt to bring it to light.

\section{Where does the scandal lie?}

\footnotetext{
1 The publication of this part of Heidegger's Gesamtausgabe is still in progress, but we will dwell only on the reflections written in the years 1938-1945. Hence, we will make reference to: Heidegger, M., Überlegungen VII-IX (Schwarze Hefte 1938-1939), Gesamtausgabe 95, Klostermann, Frankfurt am Main (henceforth quoted as GA 95). - Heidegger, M., Überlegungen XII-XV (Schwarze Hefte 1939-1941), Gesamtausgabe 96, Klostermann, Frankfurt am Main (henceforth quoted as GA 96). - Heidegger, M., Anmerkungen I-V (Schwarze Hefte 1942-1948), Gesamtausgabe 97, Klostermann, Frankfurt am Main, 2015 (henceforth quoted as GA 97) From now on, whenever appropriate, we will mention together GA 95, GA 96 and GA 97 just as $B N$.

2 Faye, E., Heidegger, l'introduction du nazisme dans la philosophie : autour des séminaires inédits de 1933-1935, Paris, Albin Michel, Idées 2005

3 Jonas, H., Erinnerungen, Suhrkamp, 2005.
} 
Since the public discussion on $B N$ has been ignited by Heidegger's antiSemitic passages, let us start from there. The mention of Jews, Judaism, Jewry and the like in $B N$ is not frequent: there are less than twenty occurrences, and not all of them especially significant. Nevertheless, the crucial point is not their quantitative presence, but their conceptual integration in the theoretical development of Heidegger's thought. Thus, Heidegger tells us that Jewry (Judentum) by essence lacks a ground to place its roots (Bodenlosigkeit) and a world to which it belongs (Weltlosigkeit) (GA 95: 97). Jews are also accused of being naturally predisposed to mix in a disorderly manner with others (Durcheinandermischen) (ibid.). Moreover, in further continuity with traditional stereotypes, Jews are regarded as endowed with a peculiar talent for a soulless calculating rationality (ratio calculans):

"The reason of the Jewry's temporarily increase of power is that Western metaphysics, at least in its modern development, offered a point of insertion for the spreading of an otherwise empty rationality and a calculating ability, which have thus found shelter within 'Spirit' (Geist), without being able to grasp, in their own terms, the hidden region of decision. The more originary and inaugural the future decisions and questions become, the more inaccessible they become to this 'race'." (GA 96: 46; my transl.) ${ }^{4}$

This passage delves further into some interesting considerations concerning Husserl's philosophical contribution. Heidegger explains that his own 'attack' against Husserl was motivated by Husserl's inability to cope with the question of being (Seinsfrage), which is associated with Husserl's Jewish origins (GA 96: 47).

Heidegger also countenances in his reflections the familiar conspiratorial idea of an 'international Jewry' (internationales Judentum), able to manipulate both the imperialist-militaristic way of thinking and its humanistic-pacifist counterpart so as to render nation states impotent and entrap them in a devious process of historical machination (Machenschaft) (GA 96: 133). ${ }^{5}$

4 „Die zeitweilige Machtsteigerung des Judentums aber hat darin ihren Grund, daß die Metaphysik des Abendlandes, zumal in ihrer neuzeitlichen Entfaltung, die Ansatzstelle bot für das Sichbreitmachen einer sonst leeren Rationalität und Rechenfähigkeit, die sich auf solchem Wege eine Unterkunft im »Geist« verschaffte, ohne die verborgenen Entscheidungsbezirke von sich aus je fassen zu können. Je ursprünglicher und anfänglicher die künftigen Entscheidungen und Fragen werden, umso unzugänglicher bleiben sie dieser »Rasse«. (So ist Husserls Schritt zur phänomenologischen Betrachtung unter Absetzung gegen die psychologische Erklärung und historische Verrechnung von Meinungen von bleibender Wichtigkeit - und dennoch reicht sie nirgends in die Bezirke wesentlicher Entscheidungen (...). Mein »Angriff« gegen Husserl ist nicht gegen ihn allein gerichtet und überhaupt unwesentlich - der Angriff geht gegen das Versäumnis der Seinsfrage, d.h., gegen das Wesen der Metaphysik als solcher, auf deren Grund die Machenschaft des Seienden die Geschichte zu bestimmen vermag. (...))“ (GA 96: 46-47)

5 „Durch diese »Geschichte« kommt das Wesen der Geschichte an den Rand einer erstmaligen Entscheidung zwischen Nichts und Seyn - die imperialistisch-kriegerische und die menschheitlich-pazifistische Denkweise sind nur die zueinandergehörigen und je als Vorwand je verschieden vorgebrachten »historischen« - »Geschichte«-machenden »Gesinnungen«, in deren Bereichen keine Entscheidungen mehr möglich sind - weil sie nur Ausläufer der »Metaphysik« darstellen. Daher kann sich auch beider das »internationale Judentum « bedienen, die eine als Mittel für die andere ausrufen und bewerkstelligen - diese machenschaftliche »Geschichts«-mache verstrickt alle Mitspieler gleichermaßen in ihre Netze- 
The metaphysical status of Jewry in the Heideggerian account is probably expressed at its clearest in the following passage:

"The question about the role of world Jewry (Weltjudentum) is no racial one, but it is the metaphysical question concerning the sort of humanity (Menschentümlichkeit), which can undertake, without any restraint, the eradication of all entities from being as its worldhistorical 'task'." (GA 96: 243; my transl.) ${ }^{6}$

Here we can appreciate the crucial position attributed to Judaism in the Heideggerian vision of the 'history of being' (Seinsgeschichte). The world-Jewry, which is supposed to be able to manipulate both imperialist and pacifist instances for its own ends, would be intrinsically bent on the reduction of Being to entities. Once we recall that the oblivion of Being in favor of a single-minded interest in entities is considered by Heidegger to be the 'original sin' of the metaphysics and history of the West, we can appreciate the crucial role played by Jewry in his conceptual scheme.

Some observations written down in 1941, when the victorious march of the German army showed the onset of remarkable contretemps, clarify the sense of the epochal confrontation that, according to Heidegger, was taking place:

"The world Jewry, stirred up by the emigrants that leave Germany, is everywhere unfathomable and, with all display of power, has no need to engage anywhere in warring deeds, whereas just the sacrifice of the best blood of the best ones of our own people is left to us." (GA 96: 262; my transl.) ${ }^{7}$

And in a later passage (1942) Heidegger deems the prospect of a Jewish world domination to be a fait accompli: the Jewish essence pervasively holds sway, so much so, that even the fight against Judaism would turn out to be in its power. This leads to the paradoxical outcome of conceiving the (then) historical present as a process of self-destruction (Selbstvernichtung) of the Jewish essence (GA 97: 20). This drastic conclusion is intelligible in light of the idea that Judaism is "the principle of destruction in the epoch of the Christian West (that is, of metaphysics)." 8

These judgments (among others, that we will not quote here) are certainly disconcerting, and after Auschwitz we are inclined understandably to single them out in the reading of the $B N$. Yet, in the context of evaluating Heidegger's thought,

; im Umkreis der Machenschaft gibt es »lächerliche Staaten«, aber auch lächerliche Kulturmache." (GA 96: 133)

6 „Die Frage nach der Rolle des Weltjudentums ist keine rassische, sondern die metaphysische Frage nach der Art von Menschentümlichkeit, die schlechthin ungebunden die Entwurzelung alles Seienden aus dem Sein als weltgeschichtliche »Aufgabe« übernehmen kann." (GA 96: 243)

7 „Das Weltjudentum, aufgestachelt durch die aus Deutschland hinausgelassenen Emigranten, ist überall unfaßbar und braucht sich bei aller Machtentfaltung nirgends an kriegerischen Handlungen zu beteiligen, wogegen uns nur bleibt, das beste Blut der Besten des eigenen Volkes zu opfern." (GA 96: 262)

8 „Diese [Judenschaft] ist im Zeitraum des christlichen Abendlandes, d. h. der Metaphysik, das Prinzip der Zerstörung." (GA 97: 20) 
it would be wrong to focus singly on these remarks about Judaism. More significant is the fact that in $B N$ the concrete protagonists of Seinsgeschichte, of its erratic course and its struggles, are essentially national peoples, interpreted as bearers of a characterizing 'essence'. While the remarks on Jewish people and culture in $B N$ are often disturbing, though admittedly not numerous, the same pages are literally replete with remarks about the nature of national peoples, their destinies and conflicts: next to Judentum, we find plenty of remarks about Germanity (Deutschtum), Russian nature (Russentum), Americanism (Amerikanismus), but also sweeping judgments about the national essence of the English, the Italian, etc. ${ }^{9}$

Thus, we learn from Heidegger that being German means nothing less than: "to throw the most interior weight of the history of the West before oneself and to take it on one's own shoulders" (GA 95: 1) ${ }^{10}$ and that "the principle of Germans is the struggle for their own most proper essence". ${ }^{11}$

On the other hand, the English 'spirit' is inflicted with the mediocrity of calculation and manifests the metaphysical inability to take on essential historical decisions. And indeed, the English metaphysical mediocrity is patently displayed, in Heidegger's eyes, by the fact that "in the last decade only in England my thought and questions have always been rejected, nor was any attempt of translation made." (GA 96: 115; my transl.) ${ }^{12}$

As to the Russian essence, we are told, among other things, that it has nothing in common with Bolshevism, because Bolshevism derives from western modern rational metaphysics. It is therefore incompatible with their Asiatic nature and much less with the Slav nature of the Russians and with their "Aryan fundamental essence." (GA 96: 47)

\section{Phenomenological method and historical 'turn'}

The $B N$ are permeated by similar remarks, which posit at the center stage of the 'history of being' (Seinsgeschichte) the vicissitudes of national peoples. No attempt is made to clarify what such national essences might consist of: are they supposed to be racial features? Cultural traditions? Geopolitical frameworks? Linguistic groups?

At any rate, if we set aside for a moment the references to Judaism, what strikes one most about this kind of remark is not so much its offensiveness, but its staleness. While the interpretative framework where the confrontation between

\footnotetext{
${ }^{9}$ Of course, the historical position of Jews and Judaism cannot be perfectly assimilated to the position of the other mentioned national peoples, since it concerned, at the time, a people without a nation state. However, Heidegger deals with Judaism as a 'national essence' analogous to the others, and so, for our purposes, we can presently disregard such specificity. 10 „Deutsch sein: die innerste Last der Geschichte des Abendlandes vor sich her werfen und auf die Schulter nehmen." (GA 95: 1)

11 „Das »Prinzip« der Deutschen ist der Kampf um ihr eigenstes Wesen.“ (GA 95: 11)

12 „Im englischen »Geist« sind auch »Wissen« und »Handeln« längst in die Mittelmäßigkeit der Berechnung versetzt; die metaphysische Unfähigkeit dieses »Geistes« zu wesentlichen geschichtlichen Entscheidungen der Zukunft ist entschieden. Kann es Zufall sein, daß mein Denken und Fragen im letzten Jahrzehnt einzig in England stets abgelehnt und auch keine Übersetzung versucht wurde?" (GA 96: 115)
} 
'national essences' allegedly takes place is new, this kind of judgment belongs to a well-established tradition of dealing with historical events. This tradition derives from the philosophy of history of Romanticism (especially Herder), which was validated in the public eye by the simultaneous constitution of the new liberal states; advocates of these new entities appealed to national essences because they had to replace the identities traditionally conferred by dynasties and their 'divine' descent. This nationalistic tradition gained power throughout the Nineteenth Century, and, especially in the final decades of that century, it could be found everywhere in public discussions and journalistic accounts of current affair. Reliance on racial and national characteristics as a dominant interpretive key of historical developments was the standard approach to international politics in the decades that led to the First World War (Hobsbawm 1989: 142f. ; 1990: 101f.). Yet, by the time Heidegger was writing, this approach was already old-fashioned. Different perspectives had been gaining traction for a while and powerful alternative interpretive paradigms, often inspired by the Marxian reading of history (cf. Marx 1978: 45f.), were available to historians. In France the École des Annales was active ten years before Heidegger began to write $B N$.

Of course, the very mention of historians, alas, French historians, and, still worse, French historians inspired by Marxian analyses, would be patently anathema in the framework of Heideggerian thought. But, anathemas aside, it is worth keeping this background in mind, when dwelling on Heidegger's reflections on history and its grounds.

It has been often noticed that the 'turn' in Heidegger's thought coincides with a radical 'historicization of ontology' (Thomson 2005: 45; Ruin 2005: 369370). A 'historical' paradigm becomes more and more dominant in his thought (GA65: 451). In Being and Time, a broadly Husserlian phenomenological framework is still at work. There, a theoretical foundation could unfold in static ahistorical descriptions of 'intentional' or 'behavioral' structures (as in the analytic of Dasein). Although his rejection of Husserl's method, as it was expressed in Ideas I, had already reached a mature state by the 1920 s, Heidegger takes an altogether different route only during the 1930s. This move towards historicization seems to be directly motivated by the search for a greater radicalness in the investigation of the 'question of being'. Heidegger blames Husserl's method for what he regards as the inability to justify the presuppositions of his own method (Epoché and phenomenological reduction), while nevertheless declaring his philosophical project to be truly foundational (GA 14: 97). In Heidegger's eyes the phenomenological method elaborated by Husserl after the Logical Investigations amounts to falling back into traditional metaphysical subjectivism (GA 14: 79). Husserl's phenomenological Epoché would stop being radical when relying on intentionality without questioning the being of intentionality (GA20, 150-151). We are not going to tackle here the question of the aptness of Heidegger's objections to Husserl. (As a matter of fact, we believe that they are pertinent to some extent only to the account of Ideas I, whereas they do not pose a substantive challenge to Husserl's method as it emerges with the introduction of genetic phenomenology in the 1920s. Yet, be that as it may, the point here is just to understand how the radicalization of Heidegger's claims affects the development of his thought and of his 'philosophical method'.) 
With the Epoché and the phenomenological reduction Husserl attempts to provide a sound descriptive basis on which all knowledge could rest, and thus to avoid any reliance on prejudicial assumptions. According to Heidegger, Husserl's project is not radical enough because it unwittingly takes for granted a crucial point about intentionality and subjectivity, by failing to inquire their being. According to Husserl the question of being is the last question that should be raised, since the nature of being can be rationally established only by first examining the appearance of what there is. Epoché suspends precisely the validity of all ascriptions of reality, degrees of reality, and causality, and it does so in order to avoid hasty accounts and prejudicial tacit explanations of phenomena. On the contrary, following Being and Time, Heidegger's claim can be appropriated more or less faithfully by saying that we should give priority to ontology regardless of epistemology (cf. Cerbone 2005: 248; Overgaard, 2004: 2). To this stance Husserl would have replied that we are never in a position to sensibly talk about ontology without establishing a sound 'epistemological' basis, which is what his method aspires to give. Let us now consider some implications of Heidegger's radicalism.

Heidegger's essential move against the allegedly subjectivist approach of Husserlian phenomenology consists in dropping the idea of a Cartesian model of foundation based on certainty and at the same time to 'relativize' subjectivity and intentionality. At first glance, this move may look similar to the relativism that characterizes radical historicism, according to which we and our cognitive tools are always already the outcome of a historical process, so that our knowledge can never genuinely merit the status of truth. To the extent that it can serve as critical leverage against the Husserlian approach, this simplified relativism is close to what Heidegger argues: history as Geschichte, as what happens (geschieht) is always already given in advance of the claims and the aims of phenomenological method. By elaborating a philosophical method without a prior investigation of being and its history, Husserl could not ascertain the ontological presuppositions of his own method. Yet, Heidegger is well aware of the objections against historicism that Husserl himself had developed (GA 17: 88), as much as he is aware of Husserl's criticism of the naturalistic ontology that operates as the interpretive framework of natural science (GA 17: 64). The Husserlian criticism, it must be recalled, suspended the ontological validity of the sciences as well as of historical accounts, in order to investigate their various presuppositions. Yet, Husserl's criticism of history and natural sciences is far from entailing a rejection of their results and practices: the objectivism of the sciences is criticized because of its limited rationality, which precludes the clarification of the meaning of scientific results and practices. The Heideggerian attitude is rather different. The sciences, all of them, including social sciences like history and sociology, are regarded as cooperating factors in the oblivion of being, by reducing being to nothing more than 'entities'. Natural science is an embodiment of the calculative, measuring and representational attitude (GA 95: 60) that characterizes Western metaphysics; natural sciences become simultaneously more and more useful and more and more insignificant (belanglos) (GA 95: 101). The advance of science makes real knowledge (Wissen) more and more superfluous. And the ambition of science to fight against 'dogmatism' is a mere consequence of the modern aspiration of dominating the entity (Seiende) (GA 95: 242). 
In this respect, natural science, in association with technology, are regarded as expressions of the very developmental tendency of the Western world that Heidegger fights against throughout his philosophical career. In this sense scientific results and practices are not just objects of intellectual analysis, possibly to clarify, reinterpret, re-discuss; they are threats and perils.

It is a crucial feature of Heidegger's thinking about history that he draws a distinction between authentic and inauthentic knowledge. The well-known Heideggerian opposition between history as science (Historie) and history as temporal reality (Geschichte) corresponds to the divide between an objectifying knowledge and the true ontological acquaintance with the fate (Geschick) of man. To some extent, the opposition reminds one of the old conceptual opposition between history as res gestae (Geschichte) and history as historia rerum gestarum (Historie). Yet, Geschichte is also something like a 'way of living', which is made possible by the essence of being and which may or may not be realized in fact (GA 65: 492). Still, what exactly is meant by Geschichte is not as clear as one would like. Its traits are mostly negative traits derived by opposition to the attributes of Historie. As for the positive traits of Geschichte, the reader is essentially left with a family of conceptual kinships: with being (Seinsgeschichte), with fate (Geschick), with origins (Ursprünge) and radical decisions. The meaning of Historie is much clearer. Historie is the business of historians; its dominant trait is the ambition to be a science and therefore to objectify (GA 65: 153). More eloquently, Historie is

"the explanation which establishes facts about the past out of the horizon of a calculative bustling about with the present. Beings are thereby preconceived as the orderable, the producible, and the establishable ( $1 \delta \varepsilon \dot{\varepsilon} \alpha)$." (Heidegger 1989: 388) $)^{13}$

Historie, like all sciences, is intrinsically complicit with the objectifying process that turns being into mere beings, into entities (Seiende) available for technical manipulation. Historie is then an essential part of the general process of 'machination' (Machenschaft). Therefore Historie is considered an obstacle to the radical decisions that are required by Geschichte (GA 95: 253); Historie implies the complete annihilation of the possibility to struggle for origins (GA95: 285) and brings about the undermining of the possibility of historical reflection (geschichtliche Besinnung) (GA 96: 64). Indeed, "History (Geschichte) comes to be only in the immediate leap over the "historiological" (Historische)." (Heidegger 1989: 11; GA 65: 10).

At its roots, the ultimate deficit of Historie is that the science of history can never provide a foundation to its historical relation to history (Geschichte), a foundation that only philosophy can provide (GA 40: 47).

Now, dismissive judgments about both natural and social sciences are to be found everywhere in Heidegger's texts. His judgments concerning natural science and history go well beyond critical considerations and epistemic objections: they are existential rejections, which spurn sense and practice of those scientific enterprises.

13 „Das feststellende Erklären des Vergangenen aus dem Gesichtskreis der berechnenden Betreibungen der Gegenwart. Das Seiende ist hierbei vorausgesetzt als das Bestell-, Herstell-

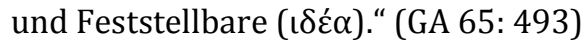


The case of history is especially interesting, because, as we noticed, Heidegger's approach apparently shares some traits with radical historicism. The difference separating Heidegger's approach from other forms of historical relativism is that Heidegger considers it necessary to 'historically' relativize even history (Historie) itself. In this sense he denies the possibility of judgments not biased by history, but denies that the science of history is in a position to establish the historical grounds of those biases. The question that opens up at this point is: what is left, if anything, in Heidegger's thought that could provide a grounding for the radical ambitions of his philosophy?

\section{Hermeneutical ontology and the effacement of method}

In our account up to this point, Heidegger's stance on the 'right way' to do philosophy has heavily depended on his rejection of the Husserlian method. But this can count at most as a negative motivation, which hangs on the plausibility of Heidegger's objections to Husserl, and which does not show that anything like a feasible alternative approach is available.

Now, although Heidegger regards the claim of a settled method to be part of the scientific, but not of the philosophical, enterprise (GA 65: 94), nevertheless he does try to develop a philosophical 'method' of his own. His method can be labeled 'hermeneutical', even if Heidegger rarely makes mention of hermeneutics in his late writings. The roots of his 'hermeneutical method' are to be found in the pages of Being and Time.

"Ontological inquiry is a possible way of interpretation which we characterized as a development and appropriation of an understanding. Every interpretation has its forehaving, its fore-sight, and its foreconception. If such an interpretation becomes an explicit task of an inquiry, the totality of these "presuppositions" (which we call the hermeneutical situation) needs to be clarified and made secure beforehand both in a fundamental experience of the "object" to be disclosed, and in terms of that experience." (Heidegger 1996: 214$)^{14}$

Here the core idea is that each act of interpretation can take place only in the wake of a previous understanding. At first sight, this thesis does not seem too distant from the transcendental design of Husserlian phenomenology: each act of apprehension, for instance in perception, takes place in the wake of intentional acts, which involve something like 'fore-sights' and 'fore-conceptions'. In fact, Husserl in the 1920s made also room for a passive dimension, where experiential sedimentation could change the content of intentional acts. Heidegger goes in an altogether different direction. He assumes that experience (interpretation) always takes place in the wake of fore-conceptions, but he rejects the transcendental route to investigate them a parte subjecti as 'conditions of possibility' of the relevant

14 "Ontologische Untersuchung ist eine mögliche Art von Auslegung, die als Ausarbeiten und Zueignen eines Verstehens gekennzeichnet wurde. Jede Auslegung hat ihre Vorhabe, ihre Vorsicht und ihren Vorgriff. Wird sie als Interpretation ausdrückliche Aufgabe einer Forschung, dann bedarf das Ganze dieser »Voraussetzungen«, das wir die hermeneutische Situation nennen, einer vorgängigen Klärung und Sicherung aus und in einer Grunderfahrung des zu erschließenden »Gegenstandes «." (GA2, 308) 
interpretation. In his opinion, interpretation always already presupposes understanding, but understanding can be understood in its turn only by looking at the interpretive acts in which it is involved. This is what Heidegger calls the hermeneutic circle: the circular interrelation of understanding and interpretation does not refer back to an endless chain of interpretive acts (as in Peirce's infinite semiosis), but must be 'statically' described. The point of this reference to circularity seems to be an appeal to immanent descriptions of phenomena, without using subjectivity as a privileged access to objectivity. No attempt is done to get out of the hermeneutic circle in order to grasp an external foundation to ground interpretation. On the contrary, according to Heidegger, the philosopher must accept this circularity and instead of trying to get out of the circle, he must enter it "in the right way" (GA 2: 202).

But how is this fore-having (Vorhabe), which enables interpretation to be understood? A substantial answer should 'solve' the question of the being of entities, which is far beyond our ambitions. Yet, what we can do is to determine what Heidegger has in mind when he talks about the fore-having and foreconception which characterize the pre-understanding of being. Thus, we learn that concepts, as 'possibility of being', are regarded as instantiations of the fore-having (Vorhabe) that enables interpretations to take place (GA 63: 16) (GA 2: 308). This does not mean that hermeneutic pre-understanding is 'nothing but' settled conceptuality, but we can say that it is in order to explain the role of something like settled concepts that the reference to the hermeneutic fore-having is made. This point suggests that what Heidegger has in mind is from the start far from the Husserlian idea of a 'natural' order of foundation of intentional acts, which could not be organized otherwise. As it were, the Heideggerian pre-conception is preconceived as 'nurture', rather than 'nature'.

Yet, the analytic of Dasein in Being and Time remains throughout a 'static' endeavor, which is compatible with Husserlian phenomenology: the 'hermeneutical situation' is analyzed into existentials, which represent a kind of 'structure' (GA 2: 134). But from $\S 45$ of Being and time onwards Heidegger begins to lament the incompleteness of this sort of analysis, which would not take temporality adequately into account (GA 2: 310). The analyses performed within the 'hermeneutical circle' are meant as something like a methodological precondition to handle history (GA 2: 524-525), while hermeneutics here is not itself historical, that is, it is not performed through historical categories. But even this approach is ultimately deemed inadequate by Heidegger ( $\mathrm{Ga} 2: 577)$. At this point, what routes remain open for the Heideggerian project?

There is a passage in Being and Time, which may help to illuminate the successive evolution of his 'methodological' choices. After denying once more that the hermeneutic circle could or should be somehow escaped, he adds:

"Common sense [Verständigkeit] misunderstands understanding. And for this reason it must also necessarily proclaim as "violent" anything lying beyond the scope of its understanding as well as any move in that direction. (...). To deny the circle, to make a secret of it or even to wish to overcome it means to anchor this misunderstanding once and for all. Rather, our attempt must aim at leaping into this "circle" primordially and completely, so that even at the beginning of our analysis of Da-sein we make sure that we have a complete view of the circular being of Da-sein. Not too much, but too little is 
"presupposed" for the ontology of Da-sein, if one "starts out with" a worldless I in order then to provide that I with an object and an ontologically baseless relation to that object." (BT, 291; GA 2: 418)

We have seen that, according to Heidegger, we must learn to enter the hermeneutic circle "in the right way". What exactly this 'right way' would consist of remains mostly obscure. As is often the case with Heidegger, what he rejects or dismisses is much clearer than what he positively proposes. In the quoted passage we may have an indication, however, of the direction which the Heideggerian approach is heading for. We can appropriately leap into the hermeneutical circle when we accept that the sphere of presuppositions is in no need to be reduced. While the original Husserlian attempt (implicitly referred to in Heidegger's reference to the 'worldless I') requires an effort to ground presuppositions, to justify, discard or relativize them in an order of foundation, Heidegger wants to push his enterprise on an altogether different path. This does not imply that Heidegger goes back to some kind of naïve realism, since realism would be just the triumph of an ontic account: the dominance of entities over the question of their being. Nor can 'leaping into the hermeneutical circle' mean the simple addition of objectual and subjective accounts. According to Heidegger, all these accounts lack awareness of their own historicality (Geschichtlichkeit), which is a constitutive element of Dasein and is expressed by the subsistence of some pre-understanding. But he rejects also the possibility that the historicality of hermeneutic situations be analyzed in ordinary historical terms, because the history of historians is always metaphysically compromised and unaware of its own presuppositions.

What are we left with, then? It may seem as though Heidegger's search for radicalness has barred all possible methodological options.

Nevertheless, Heidegger seems to believe that there is still a route that is worth trying. At the time Being and Time was published, Heidegger was lecturing on phenomenology and its method, and his account of what the 'true' method of phenomenology should be might illustrate the direction that his thought was taking. The phenomenological method, as he was then inclined to interpret it, should consist of three elements: reduction, construction and destruction (GA 24: 31). Yet, destruction is the element to which he devotes special attention, and it is in fact the trait that is the farthest from the Husserlian understanding of phenomenological method. By 'destruction' Heidegger means a peculiar process:

"[D]estruction, that is to say, a de-constructing of traditional concepts carried out in a historical recursion to the tradition. And this is not a negation of the tradition or a condemnation of it as worthless: quite the reverse, it signifies precisely a positive appropriation of tradition. Because destruction belongs to construction, philosophical cognition is essentially at the same time, in a certain sense, historical cognition. "History of philosophy," as it is called, belongs to the concept of philosophy as science, to the concept of phenomenological investigation.” (Heidegger 1982: 23)

Here we see at its clearest the shape that the examination of philosophical pre-conceptions is taking. It is not a matter of suspending the validity of philosophical preconceptions in order to give them a transcendental foundation (as in Husserl), but it is rather a matter of critically embracing the tradition that 
generates those pre-conceptions. Indeed, as Heidegger says in a previous quote, the problem of a transcendental reduction is not that it presupposes too much, but too little: philosophical pre-conceptions must not be rejected, but critically appropriated. This is the road that Heidegger seems to regard as still open. It is not the objectivistic realism of common sense or of natural science, it is neither the transcendental reduction of phenomena to their subjective conditions of possibility, and it keeps aloof from the historicist reliance on historical data.

So, in the end, it seems that the clarification of the hermeneutic situation is just assigned to a special reading of the history of philosophy. Yet, Heidegger's radicalness does not want to rely on the epistemic criteria of the history of philosophy either, hence he devotes himself to a reading of the history of philosophy that goes beyond the intentions of philosophical authors; and, indeed, Heidegger claims the right to exercise interpretive violence on them, whenever he deems it appropriate (GA 65: 253). In fact, he tries to gain a more originary access to the thoughts of classical philosophers by resorting to etymological analyses. But, again, also with reference to etymologies, he does not want to be too heavily constrained by them (GA 40: 219) and in fact such etymological analyses turn out to be often highly idiosyncratic (White 2005: 125; Wrathall 2005: 341; Friedländer 1964: 233f.).

Let us schematically recapitulate Heidegger's path towards a 'radicalization' of philosophical thinking. His search for an access to philosophical truth exempt from settled prejudices initially brought him to Husserlian phenomenology. Then, the transcendental-idealistic turn of Husserl's thought in Ideas I pushed his search to avoid not just the pitfall of objectivism denounced by Husserl, but also the hypostatization of subjectivity, that Heidegger perceived in Husserl's idealistic proposals. This was the step that led him to the hermeneutic ontology of Being and Time, where, however, the phenomenological project of an ontological foundation through the identification of an essential 'structure' (of Dasein) was still at work. But, as we saw, Heidegger mistrusted the traditional categories of philosophical investigation, since he conceived of them as foreconceptions that could not be escaped while resorting to the static description of phenomena. This urged him to emphasize the 'de-constructive' character of his analysis by deepening its character of historical retrogression. However, in order to preserve the radicalness that he claimed, the very critical and historical categories operating within such retrogression had to undergo conceptual 'destruction'. This led to a hermeneutic historical thought, which was unmoored from history as science (Historie). Finally, the only sphere of thought that remained accessible to an alleged 'radical' investigation was the history of Western thought, but only in a fashion that rejected all traditional criteria of interpretation.

For a philosophical endeavor that aimed at radical ontological questioning, refractory to settled prejudices, it is somewhat paradoxical that it found its haven in the circumscribed domain of the history of Western philosophy. In this enclosure, freedom was obtained by producing investigations that did not rely on any traditional criterion of truth and falsity, empirical or logical. In the end, the paradoxical outcome is that a thought that had the ambition to tackle the most comprehensive of all possible questions, the question of being, ends up producing analyses of the history of philosophy, whose only 'epistemic' guide is the author's 
confidence in his own 'philosophical instinct'. Such a massive restriction of the possible field of inquiry, and of its possible methods, may appear as a rather claustrophobic outcome if compared with the inaugural claims of a fundamental ontology in Being and Time.

Is this a sufficient reason to criticize the ultimate issues of Heidegger's reflection? One might doubt it. After all, he apparently displayed keen awareness of all the steps that led him in that direction. And he even vindicated the erratic and 'inconclusive' character of his reflections as a philosophical virtue. Thus, it may seem that one may like or dislike his writings, but that there is little room for 'immanent' objections, showing internal inconsistencies in Heidegger's attempt. This is not our conviction, however.

\section{Conclusions: Back to the Black Notebooks}

A style of thinking that accepts its fallibility and its tentative character, that vindicates its openness and even its ambiguity may nevertheless have its own sort of legitimacy. It may be liked or disliked, but it can always claim to play a role in preserving categorizations from dogmatism and rigidity, to provide a form of brainstorming, to open questions and keep open approaches that do not belong to the main stream. As Heidegger is right to remark, errors are not the worst that may happen to philosophical thoughts and, on the contrary, they may be fecund.

Yet, this is not the whole story with regard to Heidegger's claims. Heidegger's thought has progressively built for itself a peculiar position, which Trawny appropriately defines 'an-archic', that is, lacking any principle $\left(\alpha \rho \chi \eta^{\prime}\right)$. And Trawny clarifies what such position would amount to in Heidegger's own eyes:

"The an-archic freedom of thinking demands, as an-archic questioning, a "freedom for error." (...) An-archic thinking goes on an odyssey [Irrfahrt]. The alternative - the technical procedure [Verfahren] of science - is its untragic end. Being without error is technical routine. Thinking ceases." (Trawny 2015: 63)

Indeed, there is no doubt that Heidegger was highly aware of how he ended up in such a position, involving a style of thinking which is intentionally nonargumentative, conceptually slippery, methodologically unsettled, explicitly tentative and skeptical about all traditional scholarship. The problem however is whether his self-awareness, and his implicit claim to a 'freedom for error', confer special rights to this style of thinking. Indeed, the aspect of 'exploratory process', that wittingly characterizes his thought, by rejecting any appeal to first evidences or settled methods, is fully entitled to offer poetic suggestions, subtle inklings, radical questions. Yet, are these the only significant features of Heidegger's late writings?

This is precisely the point where the publication of the Black Notebooks turns out to be a crucial piece in the interpretive mosaic of Heidegger's Denkweg (or at least of its development after the 'turn'). Indeed, one may occasionally find statements similar to most of $B N$ 's previously discussed theses also in other published works (for instance in GA 65). Yet, what the $B N$ contribute is that they display Heidegger's thought in a less cautious and more frank fashion than it is to be found elsewhere. Few contents are completely new, but they occur with a 
frequency, and in a style, which present a clearer picture than usual. And this allows the reader to perceive in the foreground attitudes and theses which were previously camouflaged in the background. What becomes clear in the $B N$ is that in the 1930s Heidegger's thought, while becoming more and more unanchored from traditional philosophical reasons (proofs, data, inferences, public criteria, etc.), is apparently more prone than ever to take assertive and judgmental stances.

Far from being a display of modesty and tentativeness, of poetic suggestions and cautious wanderings, the $B N$ are extremely judgmental texts, where dismissive and derogatory assertions are omnipresent. The assertiveness of the text is especially remarkable with regard to two threads that run through its pages. On the one hand, as we have previously seen, we find plenty of sheer prejudices concerning national peoples, their characters and their presumed fate. On the other hand, but not unrelated to the former, we find the features of an ambitious (and openly pessimistic) 'philosophy of history'.

As we previously observed, the judgments concerning Jewry, which are bound to stand out to the reader for obvious reasons, are a small subset in a vast set of judgments where the fates of national peoples become true 'figures of Spirit' with a quasi-Hegelian flavor. Yet, they are 'figures of Spirit' without any of the justifications that Hegel, rightly or wrongly, adduced in his own account of worldhistorical figures. If we look for the empirical origins of this theoretical trait, we can probably identify its roots in Heidegger's appreciation of Herder's vision (GA56, 133-134). Still, it is hard to see why a particular historico-philosophical source, in the absence of tenable reasons, should be granted greater authoritativeness than alternative sources in history, or history of philosophy.

When it comes to what is meant by such reference to the essence of 'national peoples', the reader is left without the slightest clue. Is the nature of peoples a matter of 'blood'? Of 'culture'? Of 'language'? What counts as 'intrinsically belonging' to a people and what not? And why? If, as Heidegger said of his own work, we had to do with paths, rather than works, that is, if nothing more than a 'tentative' exploratory reflection was at stake, then we might accept the poverty of reasons that support Heidegger's theses on such issues. However, this comes at a price: he does not have the slightest legitimation to express trenchant judgments on anything, much less on macroscopic issues like the fate of national peoples or even the destiny of being as such. Unfortunately this is precisely what he is prone to do.

Heidegger shows a constant inclination to produce historical hypostatizations whose bases are, apparently, nothing more than prejudicial beliefs or contingent historical events. Thus, for instance, National-socialism "remains independent of its contemporary configuration and of the duration of its contingent visible form" (GA 95: 408). The point here is not that one could not find reasons and arguments to eventually give some credibility to the notion of a more than contingent 'essence' of Nazism. The point is that no such effort is in sight in Heidegger's writing, which can lead only to the disappointing conclusion that in it all we hear are the echoes of his personal prejudices. And this is a rather 
paradoxical outcome for a thought which dismissed all traditional epistemic criteria because of their alleged shallowness. ${ }^{15}$

To further elaborate the point we could produce many further examples drawn from the $B N$. Thus, for instance, we know that the relations between Germany and England, which had been characterized by mutual respect until the Munich agreement, radically degenerated in 1939. And in 1940 we find Heidegger complaining that "we have recognized so late that England is truly, in fact and in principle, devoid of any Western attitude" while being under the influence of Americanism, Bolshevism and therefore of World Jewry (GA 96: 243). It is difficult to resist the impression that a contingent event has been blithely hypostasized into a world-historical judgment.

Similarly, after Mussolini's declaration of war to Greece $\left(18^{\text {th }}\right.$ November 1940), we find Heidegger drawing world-historical conclusions about the "Italian hatred against Greeks and the intention to annihilate them", purportedly motivated by the "unconfessed awareness" that Greece and not Rome was at the roots of Western history (GA 96: 205). Yet, whoever has any acquaintance with the historical relations between Italians and Greeks before, and even after, the Fascist aggression, should be taken aback by the manifest groundlessness of such metaphysical assessment.

These sweeping and groundless generalizations push our attention to another class of judgments. The manifest lack of historical justification for a plurality of historical judgments should draw our attention to the framework, from which those judgments draw their only apparent justification: the picture of Western history as history of the oblivion of being. And here, again, we find many trenchant statements whose justification is perplexingly wanting. How are we supposed to relate to statements like "the oblivion of being (...) belongs to the essence of being itself" (GA 14: 37) or "Beyng itself is "tragic," (GA 95: 417)? Manifestly (and consistently with Heidegger's own considerations), there is no possible cognitive position from which judgments concerning the nature of being as such could ever be justified. From what point of view, aside from subjective inspiration, could Heidegger access reasons for saying what essentially (not contingently) belongs to being in itself?

Of course, against this, as against any other possible objection, Heidegger has always already provided in advance an overriding defense: metaphysical discourse of the kind that Heidegger inaugurates does not lay claims to objective validity and rejects from the very beginning any argumentative and demonstrative

\footnotetext{
15 On this passage one of the reviewers of the paper has suggested that "Here the author(s) could further argue against Heidegger that, as the war finally showed, the essence of Nazism was antisemitism. Heidegger's belief in a higher essence of Nazism was nothing more than willful blindness mixed with harebrained ideas about German salvific destiny." - Yet, I have chosen not to follow this suggestion, for two reasons. First, because the idea that the essence of Nazism is antisemitism is not obvious to me and would require the introduction of a specific argument. Secondly, because I am not convinced that introducing such novel issue here would provide a clarifying contribution to the core argument, which focusses on Heidegger's inclination to produce historical hypostatizations.
} 
attitude. This is what Trawny aptly names Heidegger's "freedom to fail". But, come to this point, a response is mature.

Granted that there are many forms of legitimate intellectual activity, some of these forms, among which philosophy has been always prominent, raise a claim to truth and to the authority of reasons. Heidegger's Denkweg after the 'turn' has consciously abandoned that horizon. This move, however, has not involved the relinquishment of ambitious and demanding claims, which give expression to welldefined beliefs and relevant commitments. And here, a reading of the $B N$ seems to lead forcefully to the following conclusion: the evolution of Heidegger's thought leaves him in the end without the theoretical instruments that could enable him to discriminate between deeply felt prejudices and proper philosophical intuitions. A lavish profusion of radical questioning, inclusive of self-questioning and selfcritique, has paradoxically led to the self-confident assertion of personal prejudices.

If this is the case, perhaps we should ultimately draw a stronger conclusion about the development of Heidegger's thought: we should not just question the sense of the erroneous-erratic character of such development, but, more bluntly, we should consider the possibility of its failure. It is not just a matter of a style of thinking where the journey is more significant than the result. Heidegger's course of thinking from the 1930s onwards seems to lead to a philosophical failure in the most straightforward and unmitigated of ways.

It is a failure, first, insofar as it does not provide any reason why its theses, criticisms, assertions, and dismissals should be granted any validity beyond subjective self-confidence. Secondly, it is a failure because it does not provide any way to establish, not even for Heidegger himself, how or even whether any claim could be susceptible to failure. That is, it is a failure not just because it hosts (and elaborately justifies) sheer prejudices, but because it lacks any theoretical tool that could identify them as such.

Yet, such criticisms might be still regarded as 'external' criticisms, ones that would be acceptable to those who are not sympathetic with Heidegger's thought, while being disregarded by the others. Yet, there is a criticism that can be lodged in Heidegger's own terms and which, therefore, should have relevance also for those who are appreciative of Heidegger's contributions, starting from Being and time.

The impossibility to rely just on settled knowledge and procedures is customary in philosophical enterprises. In each philosophical writing, and often especially in the most interesting ones, a collaboration between the expressive effort of the writer and a sympathetic effort by the reader is indispensable to bring to light non obvious intuitions. This was an explicit trait in the phenomenological tradition inaugurated by Husserl: methodologically mindful descriptions of firstperson experience had priority over the reliance on scientific data and logical inferences (without denying them). By activating too early a dialectical and argumentative attitude, one rules out many avenues of theoretical explorations and engenders a tendency to the mere consolidation of orthodox legacies.

Now, Heidegger is certainly one of the authors that have been most acutely aware of this demand in doing philosophy. Yet, paradoxically, his theoretical development devolves into a style of thinking that badly damages the very philosophical attitude that he was endorsing. In fact, in the wake of the internal 
evolution (and final disappearance) of his 'method', Heidegger massively abuses the tacit appeal to a 'principle of charity' in the collaboration between author and reader. The publication of the $B N$ makes explicit a theoretical evolution that was already discernible in his work, but in less clear terms. In most of the texts (and lectures) after the mid-1930s Heidegger replaces argument and phenomenological description with a more and more assertive and often oracular style, down to the incorporation of sheer subjective prejudices into his overall metaphysical framework. In this sense Heidegger's late writings unwittingly do a disservice to an important trait of free and ambitious philosophical activity.

In conclusion, there is no doubt that the publication of $B N$ will be a good chance for anti-Heideggerians to ban or jettison Heidegger's thought. One may or may not consider this a loss. But a far greater loss, easily associated with the former rejection, would be the growth of a generalized discredit towards any style of thinking that resorts to tools that go beyond the most settled apparatus of postulates, scientific truths, and logical inferences. This would be a move towards the impoverishment of philosophical reflection, for which Heidegger should be held responsible not in terms of 'human failure' (menschliches Versagen) ${ }^{16}$, but, if there is such a thing, in the terms of a true philosophical guilt.

\section{References} 248-264.

Cerbone, D. R., (2005) "Realism and Truth", in Dreyfus \& Wrathall (2005), pp.

Dreyfus H., \& Wrathall M., (eds.) (2005) A Companion to Heidegger, Oxford, Blackwell.

Faye, E., (2005) Heidegger, l'introduction du nazisme dans la philosophie : autour des séminaires inédits de 1933-1935, Paris, Albin Michel, Idées.

Friedländer, P., (1964) Platon. Seinswahrheit und Lebenswirklichkeit, De Gruyter, Berlin.

Heidegger, M., (1975) Die Grundprobleme der Phänomenologie, Gesamtausgabe 24, Klostermann, Frankfurt am Main (quoted as GA 24).

Heidegger, M., (1977) Sein und Zeit, Gesamtausgabe 2, Klostermann, Frankfurt am Main (quoted as GA 2).

Heidegger, M., (1979) Prolegomena zur Geschichte des Zeitbegriffs, Gesamtausgabe 20, Klostermann, Frankfurt am Main (quoted as GA 20).

Heidegger, M., (1982) The Basic Problems of Phenomenology, transl. by Hofstadter A., Indiana University Press.

Heidegger, M., (1983) Einführung in die Metaphysik, Gesamtausgabe 40, Klostermann, Frankfurt am Main (quoted as GA 40).

Heidegger, M., (1987) Zur Bestimmung der Philosophie, Gesamtausgabe 56, Klostermann, Frankfurt am Main (quoted as GA 56).

Heidegger, M., (1988) Ontologie (Hermeneutik der Faktizität), Gesamtausgabe 63, Klostermann, Frankfurt am Main (quoted as GA 63).

Heidegger, M., (1989) Beiträge zur Philosophie (Vom Ereignis), Gesamtausgabe 65, Klostermann, Frankfurt am Main (quoted as GA 65).

16 "Menschliches Versagen" is the expression that Heidegger used in his famous last interview to Der Spiegel, to apologize for his behavior in the occasion of Husserl's death. 
Heidegger, M., (1989) Contributions to Philosophy (Of the Event), transl. by Rojcewicz R. and Vallega-Neu D., Indiana University Press.

Heidegger, M., (1994) Einführung in die Phänomenologische Forschung, Gesamtausgabe 17, Klostermann, Frankfurt am Main (quoted as GA 17).

Heidegger, M., (1996) Being and Time, transl. by Staumbaugh J., State University of New York Press.

Heidegger, M., (2007) Zur Sache des Denkens, Gesamtausgabe 14, Klostermann, Frankfurt am Main (quoted as GA 14).

Heidegger, M., (2014) Überlegungen VII-IX (Schwarze Hefte 1938-1939), Gesamtausgabe 95, Klostermann, Frankfurt am Main (quoted as GA 95).

Heidegger, M., (2014) Überlegungen XII-XV (Schwarze Hefte 1939-1941), Gesamtausgabe 96, Klostermann, Frankfurt am Main (quoted as GA 96).

Heidegger, M., (2015) Anmerkungen I-V (Schwarze Hefte 1942-1948), Gesamtausgabe 97, Klostermann, Frankfurt am Main, 2015 (quoted as GA 97).

Hobsbawm, E. J., The Age of Empire 1875-1914, Vintage Books, 1989.

Hobsbawm, E. J., Nations and Nationalism since 1780. Programme, Myth, Reality, Cambridge University Press, 1990.

Jonas, H., Erinnerungen, Suhrkamp, 2005.

Marx, K., The Class Struggles in France, 1848 to 1850, in Karl Marx and Friedrich Engels - Collected Works 1849-1851, vol. 10, International Publishers 1978, pp. 45-146.

Overgaard S., (2004) Husserl and Heidegger on Being in the World, Dordrecht, Kluwer. 358-374.

Ruin, H., (2005) "Contributions to Philosophy”, in Dreyfus \& Wrathall (2005), pp.

Thomson, I., (2005), "Heidegger and National Socialism", in Dreyfus \& Wrathall (2005), pp. 32-48. Press.

Trawny, P., (2015) Freedom to Fail: Heidegger's Anarchy, Cambridge, Polity pp. 121-140.

White, C. J., (2005) "Heidegger and the Greeks", in Dreyfus \& Wrathall (2005),

Wrathall, M., (2005) "Unconcealment", in Dreyfus \& Wrathall (2005), pp. 337357. 